\title{
Idrættens forbudte forhold
}

\section{Af Jan ToftegaArd Nielsen}

Hvad er det der sker, når legen går for vidt, og den idvatslige intimitet mellem frivillige tranere og ungdomsudøvere udvikler sig til seksuelle krankelsesforhold? Ved hjalp af en kriminalistisk undersøgelse af 160 domsafgjorte anmeldelser ser artiklen narmer på omfang og krankelsesdynamik og diskuterer velevante konsperspektiver.

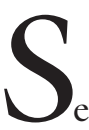

elvom tolerancen

over for individets seksualitet og seksuelle udtryksformer sandsynligvis aldrig har været større end den er i dag, så har der inden for de seneste år været en kraftig fokusering på forbudte seksuelle relationer mellem børn og voksne. I takt med en stribe medieafsløringer af krænkelsesforløb inden for daginstitutionerne, spejderbevægelsen, idrætten og senest de kirkelige organisationer er der skabt opmærksomhed om den immanente risiko for udnyttelse, der findes i de sammenhænge, hvor børn og unge færdes. Problemstillingen er interessant i forhold til køn, fordi det i idræt tilsyneladende kun er mandlige trænere, der indleder seksuelle handlinger med børn og unge, og fordi drenge synes at være mere udsatte end piger. Seksuelle krænkelser i idræt er ikke noget nyt frenomen og har sandsynligvis været kendt på anekdotisk niveau fra idrættens start. Inden for de seneste 5 år har der været adskillige medieomtalte krænkelsessager, som har skabt opmærksomhed 
om den såkaldte skolelærerparagraf - $\$ 223$. Ifølge Straffelovens $\$ \$ S$ 223-224 er seksuelle relationer $\mathrm{i}$ form af samleje og anden kønslig omgxngelse med personer under 18 år ulovligt og kan straffes med fængsel ind til 4 år. Den juridiske begrundelse for at operere med en beskyttelse, der ligger ud over den kriminelle lavalder på 15 år, fremgår eksplicit af lovteksten: “Der er en særlig mulighed for misbrug af stillingen som lærer til at skaffe sig et forhold til eleven." (\$ 223 stk. 2). Idet træner/udøverforholdet sidestilles med lærer-elev forholdet er loven således gældende for idrætstrænere, spejderledere og andre, der er betroet til undervisning eller opdragelse. Den udvidede beskyttelse af børn og unge op til 18 år fremstår særlig relevant set i lyset af de alvorlige konsekvenser, det kan medføre for udøverne som bl.a.: tab af selvværd, trang til isolation, angst for at være alene, depression, spiseforstyrrelser, kønssygdomme, uønskede graviditeter, selvhad, selvmordstanker og selvmordsforsøg. ${ }^{1}$

\section{Problemstillingens FØLSOMHED OG KOMPLEKSITET}

Idrætstræneres seksuelle krænkelser af børn og unge er en tabuiseret problemstilling på individuelt, organisatorisk og institutionelt niveau. Idrættens hovedidrætsorganisationer er i de senere år gået gennem forskellige stadier af benægtelse og befinder sig på nuværende tidspunkt i en situation, hvor man erkender at stå overfor et reelt problem, som man dels må forsøge at forebygge og dels forholde sig til i takt med at sagerne opstår. Som følge af den institutionelle blindhed overfor problemet har hverken idrætsforeninger, trænere, krænkede udøvere samt deres forældre kunnet få information eller støtte i forbindelse med konkrete sager. Foreninger har typisk reageret med at afvente den politimæssige efterforskning og juridiske domfældelse, før man har kunnet tage stilling til eventuelle konsekvenser. Den institutionelle og organisatoriske tabu- isering er især knyttet til idrættens selvforståelse, som indebærer, at trænere og ledere er mindre tilbøjelige til at forholde sig kritisk i forhold til adfærdskulturer, man selv er en del af. Idrætten foregår i en frivillighedssfære omgivet af positive værdier som xgte engagement, kammeratskab og fællesskab og det er netop frivillighedens særlige uangribelige karakter, som gør, at nogle trænere er i stand til at føre legen meget langt ud. Ikke overraskende nægter de fleste krænkere alle anklager om seksuelle krænkelser, og da træneren ofte er en betroet medarbejder $\mathrm{i}$ foreningen og en respekteret person i lokalmiljøet, betyder det, at foreningsbestyrelserne ofte bliver rådvilde og handlingslammede og derfor undlader at foretage sig noget.

På det individuelle niveau består tabuiseringen af de krænkede udøveres følelser af skyld, medskyld og skam, der paradoksalt nok bidrager til at beskytte krænkerne mod afsløring og politianmeldelse. Chefkriminalinspektør ved Københavns Politi, Per Larsen, fremhæver i den forbindelse, at man må forvente, at mørketallet i forbindelse med idrætsrelaterede krænkelsessager vil være højere end sammenlignet med andre ekstrafamiliære områder. Når han siger dette, hentyder han blandt andet til de særlige tillids- og afhængighedsrelationer, som findes inden for idrætten, hvor begreber som loyalitet og frivillighed fremstår som nøgleord.

\section{TEORI OG TIDLIGERE FORSKNING}

Som følge af fænomenets følsomme karakter findes der indtil videre kun få undersøgelser og statistisk materiale, som belyser problemets omfang og karakter. Den eksisterende viden om generel krænkelsesdynamik kommer i overvejende grad fra den kliniske psykologi og forskningen om misbrug indenfor familien samt sexchikane på arbejdsmarkedet. Selvom der findes betydelige fællesmængder mellem de forskellige forskningsfelter (familien, arbejdsmarkedet 
og idrætten), så må den idrætsspecifikke forskning fortsat betegnes som værende i en pionerfase.

I en dansk omfangsundersøgelse fra 1988 blandt et repræsentativt udsnit af den danske voksenbefolkning finder Leth m.fl., at $14 \%$ kvinder og $7 \%$ mænd udsættes for grovere seksuelle krænkelser inden det fyldte 18 år (Leth m.fl., 1988). $60 \%$ af alle krænkelser var foregået uden for hjemmet, dvs. i idræt, i skolen, institutioner eller andre fritidsmæssige sammenhænge. Kun ca. $25 \%$ havde foretaget politianmeldelse, hvilket betyder, at der var et tilsvarende mørketal på $75 \%$. I en baggrundsundersøgelse for Det tværministerielle Børneudvalg konkluderer speciallæge Karin HelwegLarsen $(2000,11)$, at mindst 1 \% i løbet af barndommen vil blive udsat for et seksuelt overgreb. På baggrund af informationer fra politiet, sundhedsvæsnet, BUPL, PMF og DL skriver forfatteren i den samme konklusion, at det er rimeligt at antage, at forekomsten af overgreb sandsynligvis andrager $5 \% .^{2}$ I 2002 viser resultaterne af en spørgeskemaundersøgelse blandt 5.829 9.kl. skoleelever, at $16 \%$ af pigerne og $7 \%$ af drengene havde haft seksuelle erfaringer med voksne før det fyldte 15. år (HelwegLarsen, 2003). Trods definitionsmæssige forskelle og forskellige procentsatser, ${ }^{3}$ så viser de seneste 15 års erfaringer og 13 nordiske prævalensundersøgelser, at kriminelle seksuelle handlinger mellem voksne og børn og unge udgør et væsentligt problem, som er præget af en massiv underrapportering og en heraf manglende behandlingsmæssig indsats. I forhold til det idrætsspecifikke felt findes der kun få danske undersøgelser, der belyser problemets størrelse og karakter.

I min undersøgelse fra 1998 som indeholder spørgeskemaundersøgelser blandt 275 trænere og 253 udøvere samt opfølgende interviews, anslås omfanget af seksuelle krænkelser til at være mellem 2 og $5 \%$. Disse tal passer nogenlunde overens med de tal, der nævnes i undersøgelser foretaget i Norge, Canada og Australien. ${ }^{4}$ Derimod finder Helweg-Larsen i spørgeundersøgelsen blandt skoleelever fra 2002, at kun 0,2 $\%(\mathrm{~N}=14)$ af de adspurgte unge havde oplevet seksuel kontakt med en træner. ${ }^{5}$ Undersøgelserne blandt trænere og udøvere viser endvidere, at parterne havde divergerende opfattelser af, hvad der var acceptabel adfærd i og omkring det idrætslige samvær. Resultaterne af undersøgelserne blandt trænere og udøvere gav anledning til at opstille en teori, som søger at forklare hvordan seksuelle krænkelser udvikler sig på baggrund af en række magtformer samt en længerevarende grænsenedbrydningsproces. Som en forudsætning for at forstå den asymmetriske relation mellem træner og udøver er det vigtigt dels at forstå, hvordan børn og unges idolisering af deres træner samt generelt naive viden på det emotionelle plan kan medføre en sårbarhed som relativt let kan udnyttes. Trænerens magtformer omfatter endvidere viden om aktiviteten og dens udførelse, hierarkisk magt (hvor træner bestemmer og udøver adlyder), magten til at belønne og fratage belønning samt en fysisk og kønsrollemæssigt bestemt magt. Grænsenedbrydningsprocessen består af tre overlappende faser med en indledende tillidsopbygning, en forførelsesfase og ultimativt en krænkelsesfase. Centralt i forståelsen af grænsenedbrydningsprocessen er, at den grænsenedbrydende adfærd sker på baggrund af overtalelse og velvilje snarere end ved tvang, og derfor kan adfærden måske bedst forstås som successive forhandlinger - eller nærmest umærkelige overskridelser af - udøverens fysiske og psykiske intimitetsgrænser. Det, der adskiller den almindeligt accepterede grænsenedbrydning, som almindeligvis foregår $i$ idrætten, fra den problematiske, er blandt andet, når træneren verbalt eller fysisk overskrider udøverens kritiske distance og foretager seksuelle tilnærmelser og/eller gennemfører magtfuld seksuel adfærd. Den grænsenedbrydende adfærd tager ofte afsæt $\mathrm{i}$ instruktionsrelaterede handlinger for der- 
efter, afhængig af trænerens motivation og intentionalitet, at bevæge sig i retning af ikke-instruktionsrelaterede adfærdsformer. Dette sker ofte via en pro- og regressionsstrategi, hvor træneren i dobbelt forstand har mulighed for at føle sig frem og dermed sikre sig udøverens samarbejde.

Den internationale forskning på området er i vid udstrækning afledt af det teoretiske, metodiske og empiriske arbejde som den engelske sociolog Celia Brackenridge har foretaget. I relation til nærværende artikel vil jeg fremhæve Brackenridge s contingencyteori, ${ }^{6}$ der i korte træk handler om, hvordan seksuel udnyttelse kan ses som et samlet produkt af forskellige risikofaktorer. Her har Brackenridge især fokuseret på trænerens tilbøjelighed til at krænke, udøverens sårbarhed $\mathrm{i}$ forhold til krænkende adfærd og endelig de faktorer ved sportens kulturer og strukturer som muliggør krænkende adfærd (Brackenridge, 1990, 1994, 1997a+b, 2001).

I år 2000 påbegyndte Brackenridge etableringen af ABISS-databasen (abuse in sport statistics) - en database til registrering og opsamling af nationale og international krænkelsessager. Indledningsvis med mere end 200 variable, men er senere blevet reduceret til omkring 60 for at gøre den mere håndterbar og overskuelig. Da databasen endnu ikke er færdigudviklet, findes der endnu ikke mulighed for at foretage resultatmæssige sammenligninger.

Hvor den engelske database i nogen grad søger belysning af sagsbebandlingsforløb og organisatorisk respons, så er formålet med den danske KISS-database i højere grad at belyse individuelle og interpersonelle risikofaktorer. En anden forskel er, at KISS-undersøgelsen beror på en indsamling af domsafgjorte krænkelsessager, hvori krænkeren er blevet ikendt straf. Den kriminalistiske metode er blandt anvendt for at kunne gennemgå de skriftlige sagsakter og derigennem opnå så præcise informationer som muligt om de 48 udvalgte variable. Formålet med KISS-databasen, som er en delundersøgelse fra min ph.d.afhandling Idrettens illusoriske Intimitet, er at undersøge mønstre på tværs af krænkelsessager samt at kunne foretage trianguleringer af data fra forskellige kilder.

\section{Metodiske og ETISKE OVERVEJELSER}

Når der ikke findes tilstrækkeligt nuancerede undersøgelser og offentligt tilgængelige statistikker på dette område, så hænger det blandt andet sammen med de vanskeligheder der kan være ved at indhente empiriske resultater. Som den engelske sociolog Celia Brackenridge (1997a) fremhæver i antologien Researching Women and Sport: 'Victims of abuse do not simply step forward from nowhere". Inden man går i gang med forskning på dette område, bør man være nøje overveje de forskellige forskningsetiske- og metodiske problemstillinger, der uvilkårligt opstår, når man ønsker at opnå adgang til viden, som de fleste relevante parter ønsker at hemmeligholde, og som de offentlige myndigheder er meget påpasselige med. De vigtigste overvejelser i forhold til den anvendte forskningsetik og metode handler om, hvad man kan tillade sig overfor sårbare informanter, hvordan man håndterer deres interesser og krav på anonymitet og interesser, samtidig med at man opnår svar på følsomme undersøgelsesspørgsmål. Foruden de etiske, metodiske og praktiske problemer, der kan være med at få adgang til relevante informationer, er der ligeledes en lang række spørgsmål om fortolkning og validering af modstridende sagsoplysninger, opbevaring af følsomme persondata, og ikke mindst hvordan man som undersøger bliver påvirket af emnet og de informationer, man får kendskab til.

Denne artikel bygger isoleret set udelukkende på skriftlige kilder, hvor der ikke har været kontakt med informanter. I forbin- 
delse med indsamlingen af sagsmaterialet er der forudgående opnået tilladelse via Justitsministeriet. Politiets regionale efterforskningscenter i København (REC) har været behjælpelige med de relevante databasesøgninger og landets politikredse med fremfindelsen af de relevante sager.

\section{RESULTATER OG ANALYSE}

Det samlede datamateriale består af 160 domsafgjorte sager, som er blevet indsamlet ved rundrejse til mere end 30 politikredse. ${ }^{7}$ Sagerne er blevet indsamlet og registreret i forhold til 48 variable i forhold til krænkeren, krænkede og krænkelsen. Antallet af anmeldelser for perioden udgør 189, hvilket indebærer, at der på undersøgelsestidspunktet fortsat var 39 anmeldelser under juridisk behandling. ${ }^{8}$ I tillæg er der i alt blevet indsamlet 56 domsafgjorte spejdersager og 25 sager der vedrører øvrige fritidssfærer. Disse sager inddrages i denne artikel, hvor sammenligninger mellem de forskellige krænkelsesfelter forekommer særlig relevant.

Hvad består de indsamlede sager af?

De i alt 160 domsafgjorte idrætsrelaterede sager fordeler sig på 22 forskellige typer af sædelighedsforbrydelser. Ingen af de tilgængelige sager omhandler dom i forhold til handlinger, der har kunnet forklares med misforståede intentioner $i$ forhold til instruktionsrelaterede handlinger som fx tagved-metodik, sejrsknus, anerkendelse i form af klap i bagdelen eller lignende. Blufærdighedskrænkelser i form af berøring, fotografering, blotteri mv. udgør $22 \%$ af det samlede antal sager, og $78 \%$ af krænkelserne vedrører grovere sædelighedsforbrydelser. Denne fordeling af sædelighedsforbrydelser afspejler ikke de tal, der er gxldende for det øvige samfund, hvor blufærdighedskrænkelser tegner sig for ca. halvdelen af anmeldelserne. Når idrættens tal er anderledes kan det muligvis forklares ved tærsklerne for, hvornår man føler sig krænket når der er tale om et kropsligt og intimt område. ${ }^{9}$ Det relativt lave antal blufærdighedskrænkelser - i forhold til grovere krænkelsestyper $^{10}$ - kan også hænge sammen med bevisbyrden, der, ligesom i intrafamiliære sager, kompliceres pga. relationens nære karakter, og fordi de begåede handlinger ofte befinder sig i en gråzone, præget af misforståede intentioner og grænseoverskridende adfærd. Selvom almindelig juridisk praksis indebærer, at en forbryder skal kunne stilles til regnskab for samtlige begåede enkelthandlinger, så viser den manuelle sagsgennemgang, at der ofte er foregået en række mildere krænkelser, der udelades i det endelige anklageskrift. Når disse mildere krænkelser tilsidesættes i anklageskriftet, kan det muligvis skyldes, at anklagerens fokus er rettet mod at få krænkeren dømt efter strengeste paragraf. Inddragelse af evt. mere tvivlsom bevisførelse vedr. blufærdighedskrænkelser udelades $\mathrm{i}$ sådanne tilfælde for ikke at så tvivl om hovedsigtelsen. Dette er naturligvis interessant set $\mathrm{i}$ forhold til, at idrætsforeningerne generelt er tilbøjelige til at afvente de juridiske afgørelser, før de selv tager stilling til eventuelle konsekvenser.

\section{HVOR FOREGÅR DE}

\section{IDRÆTSRELATEREDE KRÆNKELSER?}

Foruden det geografisk bestemte gerningssted kan gerningsstedet ligeledes præciseres i forhold til private eller offentlige lokaliteter. I en række tilfælde kan det imidlertid være vanskeligt at afgøre, hvor hovedgerningsstedet er; enten som følge af at handlingen måske indledes et sted og fortsætter et andet, eller fordi der kan være tale om flere krænkelser, fordelt over en årrække. Det primære krænkelsessted er i to ud af tre af tilfælde $(\mathrm{N}=104)$ krænkerens hjem. $18 \%$ $(\mathrm{N}=29)$ er foregået i eller omkring idrætsfaciliteter (hal, omklædningsrum, taktik/- og mødelokale, styrketræningsrum mv.).

I forbindelse med 73 af de i alt 160 anmeldelser har der været tale om mere end ét gerningssted. I 46 af de 73 anmeldelser 
har det sekundære krænkelsessted været idrætsfaciliteter. De seksuelle krænkelser inden for spejderbevægelsen viser et ganske andet billede, idet $62 \%(\mathrm{~N}=32)$ af anmeldelserne har relation til spejderfaciliteter som telt, hytte, campingplads $\mathrm{mm}$. Kun hver fjerde krænkelse er her foregået i krænkerens hjem.

\section{VARIGHED AF KRÆNKELSESPERIODE}

I modsætning til mere pludselige kriminalitetsformer som voldtxgt er det i de idrætsrelaterede krænkelsessager vanskeligt at fastsætte et gerningstidspunkt og en krænkelsesperiode. Dels fordi de krænkede kan have svært ved at huske, hvornår hvilke krænkelser begyndte, og hvor længe mere enkeltstående krænkelser har varet. I diagram 1 er varighed illustreret for hvert krænkelsesområde. Ved at gå ud fra y-aksens akkumulerede værdier ses det, at ca. $13 \%$ af sagerne inden for idræt varer 4-5 år (eller kortere), ca. 20 \% 3-4 år (eller kortere) og ca. 25 \% 2-3 år (eller kortere). Når kurven for 'idræt' ligger højere placeret end de øvrige kurver, betyder det, at krænkelsesperiodens varighed inden for idræt generelt er længere end for de øvrige aktiviteter.

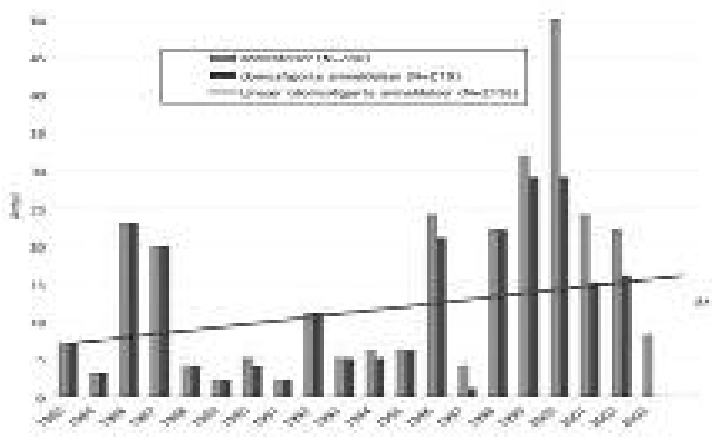

Ved aflæsning ud for $50 \%$ på Y-aksen ses det, at halvdelen af krænkelserne for idræt varer 7-12 måneder (eller kortere) mod 1-3 dage for spejderbevægelsen. Det er interes- sant at bemærke, at idræt har færre engangshændelser (under 15 minutter) end både spejder og øvrige aktiviteter.

På grund af de tidsintervaller, der er blevet anvendt ved indtastning af anmeldelserne, samt de usikkerhedsmarginer, der findes inden for de konkrete sager, er det ikke muligt at foretage en mere præcis udregning af krænkelsesperiodernes gennemsnitlige varighed.

\section{KRÆNKELSESTIDSPUNKT OG ANTAL KRÆNKELSER}

Det fremgår af de 160 idrætsrelaterede sager, at ca. en fjerdedel af krænkelserne begås $\mathrm{i}$ dagtimerne og tre fjerdedele $\mathrm{i}$ aftenog nattetimerne. Krænkelsestidspunktet er tæt knyttet til variablerne 'fremgangsmåde' og 'alkoholindtagelse'. Ved en sammenligning af krænkelsestidspunkter for idræt og spejder er der en klar tendens til, at der er foregået flere krænkelser i løbet af nattetimerne inden for spejderbevægelsen, hvilket også forekommer logisk, da flertallet af disse krænkelser begås i forbindelse med overnatning i telt eller hytte. I forlængelse heraf ses også, at der typisk går længere tid, før krænkelse i idrætsrelaterede sager bliver anmeldt. Ud fra de 235 anmeldelser, der rummer data om tid fra sidste krænkelse til anmeldelsestidspunkt, går der gennemsnitligt 25 måneder inden anmeldelse. For idrætsrelaterede sager alene er gennemsnitstiden 28 måneder. Den manuelle sagsgennemgang viser ikke en nærmere sammenhæng mellem varigheden af krænkelsesperioden og den tid, der er gået fra sidste krænkelse til anmeldelsestidspunkt. I ca. $10 \%$ af anmeldelserne har politiets efterforskning af en anden og nyere sag fort til opdagelse af krænkelsesforhold, der ikke tidligere har været anmeldt.

Antallet af begåede seksuelle krænkelser kan enten belyses ud fra de implicerede parters udsagn, anklageskriftet eller den enkelte sags domsafsigelse. I $40 \%$ af sagerne har 
der været tale om én krænkelse, mens der i $60 \%$ har været to eller flere krænkelser. Disse tal er ikke nødvendigvis udtryk for, hvad der rent faktisk måtte være foregået, men snarere et udtryk for det antal krænkelser, krænkede kan eller vil tale om på anmeldelses-, afhørings- og vidnetidspunktet. I to forskellige sager har der f.eks. været nævnt henholdsvis 85 og 500 krænkelser. Det bemærkes, at de krænkede udøvere i begge tilfælde er blevet systematisk udnyttet over adskillige år. Det fremgår af afhørings- og anholdelsesrapporterne med de senere dømte krænkere, at der er tale om et tydeligt misforhold mellem, hvad krænkeren på den ene side husker og vil indrømme, og på den anden side hvad den krænkede beretter om. Krænkerens indrømmelse af 5 tilfælde af 'anden kønslig omgang end samleje' (onani) forekommer utroværdigt, når eksempelvis flere krænkede udøvere uafhængigt af hinanden i stærk følelsesladet tilstand fortæller om flere anale samlejer om ugen gennem flere år. På baggrund af de tilgængelige sagsakter ser det ud til, at anklageskrifterne i en vis udstrækning forsøger at balancere objektiviteten i de sager, hvor krænkeren har afgivet minimal indrømmelse, eller hvor der i øvrigt er påfaldende misforhold mellem de implicerede parters afhøringer. Objektiviteten synes at blive balanceret ved, at anklageskriftet i nogen grad nedjusterer de begåede krænkelsers grovhed eller antal. Det høje antal krænkelser på 500 er således i anklageskriftet omformuleret til "adskillige". Endvidere bør det nævnes, at misforhold vedr. antallet og karakteren af krænkelser ofte påkalder sig diskussioner om elementer som falsk hukommelse, vidnemanipulation, fejlfortolkninger, fortrængninger eller usandheder. Disse elementer vil dog ikke yderligere blive diskuteret i denne artikel.

\section{INDIVIDUEL IDRÆT ELLER HOLDIDRÆT?}

De 160 sager inden for idræt repræsenterer i alt 20 forskellige idrætter. $71 \%(\mathrm{~N}=114)$ af sagerne er foregået i individuelle idrætter $\bmod 29 \%(\mathrm{~N}=46)$ i holdidrætter. Ved en inddeling af krænkelsessagerne efter det idrætslige niveau, som udøveren har befundet sig på, viser det sig at $10 \%(\mathrm{~N}=16)$ har været på et øvet eller talentorienteret niveau, og 90 \% ( $\mathrm{N}=144)$ har været knyttet til breddeidrætten. To idrætsgrene, ridning og kampsport, tegner sig for i alt 59 anmeldelser.

\section{TRUsLER, BELØNNING, ÅRSAGER TIL} IKKE AT FORTÆLLE OM KRÆNKELSERNE Pression dækker over de handlinger, der har til hensigt - mere eller mindre eksplicit - at tvinge ofret til en ønsket adfærd. Når det gælder belønning, er det krænkerens mål at lokke, narre eller snyde ofret til at samarbejde. Politiet anvender ikke begrebet pression, men derimod trusler. ${ }^{11}$ På grund af sagernes kompleksitet og de implicerede parters individuelle motiver og handlinger kan det i praksis være vanskeligt at sondre mellem de enkelte pressions- og belønningsformer, og i praksis sker der ofte en vekselvirkning mellem disse former. I 140 ud af $160(88 \%)$ tilfælde har der været tale om en eller anden form for trussel eller belønning. I 9 tilfælde findes der positiv bekræftelse af, at der hverken har været tale om trusler eller belønninger. I 11 sager findes der ikke informationer vedrørende trusler eller belønninger.

Sagsakterne viser, at der i forbindelse med 55 anmeldelser har været anvendt helt særlige metoder, som var distinktive for de enkelte krænkere. I 11 tilfælde har der for eksempel været benyttet en såkaldt smertemetode, der gik ud på at udøverne (drenge) skulle have 'noget' (penis eller objekt) op i endetarmen. ${ }^{12}$ I en sag med 23 anmeldelser benyttede krænkeren en såkaldt "skylde-seddel", der var sat op i krænkerens soveværelse. Hvis pigerne tog en sodavand, øl eller skulle have cigaretter, skulle de skri- 


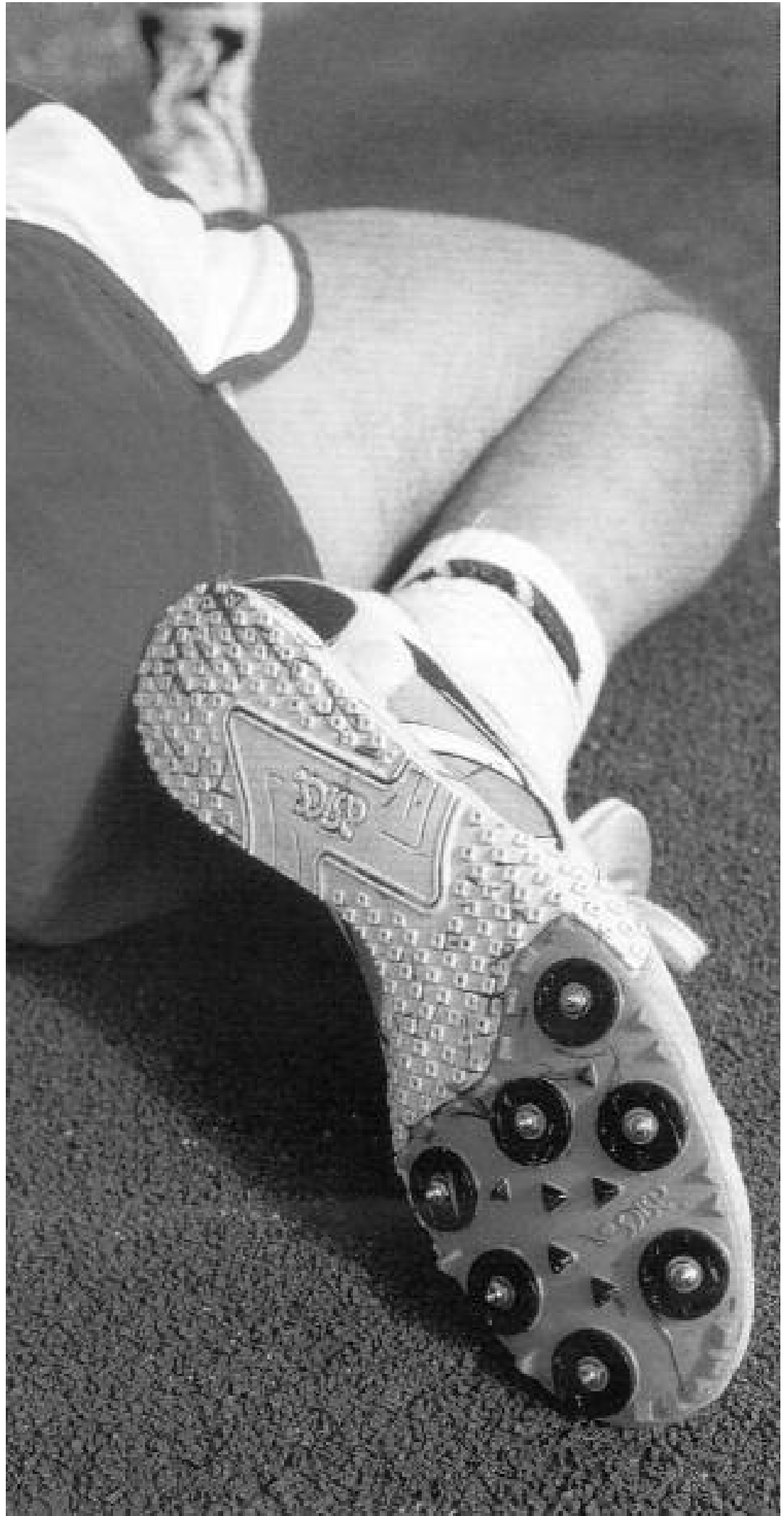

Foto: Claus

Haagensen/Chili 
ve det på skyldesedlen i soveværelset. Pigerne kunne herefter vælge at støvsuge og gøre rent for skyldebeløbet eller gå i seng med krænkeren, der i givet fald hurtigere medførte sletning af grlden end gennem husarbejde.

Under gennemlæsning af afhøringer med de krænkede er det blevet tilstræbt at foretage en så objektiv vurdering som muligt i den enkelte sag med henblik på at afgøre, hvad der har afholdt den krænkede fra at politianmelde krænkelsen umiddelbart efter handlingerne. I tre sager har udøveren været bange for voldelige repressalier fra krænkeren. I 45 tilfælde giver udøvere udtryk for, at de er bekymret over, hvordan det skal gå trænere, og hvad der kommer til at ske med dem selv. I 9 tilfælde fremgår det, at udøveren følte sig skamfuld over for venner/omgangskreds. I 12 tilfælde giver udøveren udtryk for bekymring i forhold til mor/far. Under en poliltiafhøring fortæller en pige, at hun godt vidste, det var forkert at have sex med træneren, fordi han havde fortalt hende, at det var ulovligt, og at han ville rådne op i et fængsel, hvis hun fortalte det. Hun fortxller endvidere, at han havde sagt, hun ville komme på børnehjem, fordi hendes forældre ikke ville kendes ved hende, når de fandt ud af det. Det er karakteristisk for krænkelsessagerne, at det ofte er sammenvævede forklaringer om skyld, skam og manipulationer, som afholder udøverne $i$ at fortælle det til nogen.

\section{KRÆNKERENS ALDER, UDDANNELSE, CIVILSTATUS OG EVT. TIDLIGERE BEGÅET KRIMINALITET}

I alt 40 mandlige krænkere i alderen 23 til 67 år står bag de 160 idrætsrelevante anmeldelser, hvilket gennemsnitligt svarer til 4 anmeldelse pr. krænker. Gennemsnitsalderen for trænerne er opgjort til 35 år. De 13 krænkere med den korteste skolegang tegner sig for $48 \%(\mathrm{~N}=77)$ af samtlige sager, selvom de kun udgør en tredjedel af krænkerne, hvilket dermed svarer det gene- relle kriminelle kriminalitetsbillede, hvor de mellem- og højtuddannede relativt set enten er mindre kriminelle eller bare bedre til at undgå afsløring og anmeldelse. Ud fra krænkerens samlivsstatus ses det, at $66 \%$ $(\mathrm{N}=105)$ af gerningsmændene bor alene, $13 \%(\mathrm{~N}=21)$ er samlevende med partner eller bofælle, $4 \%(\mathrm{~N}=7)$ er gift og $12 \%$ $(\mathrm{N}=19)$ er ukendt. 8 af de 40 krænkere har tidligere været dømt for $\mathrm{i}$ alt 58 alvorligere straffelovsovertredelser, herunder domme for sædelighed, svindel, afpresning og vold. To af trænerne har tidligere været dømt for sædelighedsforbrydelser, og tre af krænkerne har tidligere făet tiltalefrafald i sædelighedssager. Sammenholdt med alder og uddannelse tegner der sig et billede af, at de fleste gerningsmænd bor alene, har kort eller ingen videregående uddannelse og er i alderen 25-37 år. Selvom disse resultater kan antyde, at uddannelse, alder og samlivsstatus spiller ind i forhold til kriminalitetsgraden, så er det tilgængelige talmateriale for lille til at kunne konkludere noget absolut.

\section{DE KRÆNKEDES ANTAL, KØN, ALDER OG FAMILIEMÆSSIG BAGGRUND}

Antallet af krænkede børn/unge inden for idræt, spejderbevægelsen og øvrige aktiviteter kan opgøres til minimum $221 .{ }^{13} \mathrm{I}$ ca. 2 ud af 3 tilfælde er offeret en dreng, hvilket forekommer noget overraskende $\mathrm{i}$ forhold til den eksisterende danske og internationale forskning, hvor krænkelser mod piger har været rapporteret som den største gruppe. Ofrenes gennemsnitsalder er 12 år, lidt lavere for drenge og lidt højere for piger. Blandt de 160 idrætsrelaterede anmeldelser er de 145 med krænkede i alderen 6-14 år og 15 sager med krænkede i alderen 15-18 år.

Det er en ofte gentaget konklusion i den tidligere forskning, at seksuelle krænkelser i højere grad forekommer i socialt dårligt stillede hjem, hvor barnet/den unge enten er overladt meget til sig selv eller blot ikke 
får dækket vitale omsorgsbehov. Risikoen er muligvis større i socialt dårligtstillede kontekster, men det betyder ikke, at velfungerende børn/unge fra socialt velstillede hjem ikke kan blive krænket. Isoleret set giver det tilgængelige sagsmateriale kun sparsomme informationer om den krænkedes familiemæssige baggrund, herunder hvor barnet/den unge bor, hvor mange søskende der er, og om forældrene er skilt. I 34 tilfælde er der tydelige tegn på omsorgssvigt fra værge eller forældres side. Disse sager fordeler sig ligeligt mellem skilsmissefamilier og familier, hvor begge forældre bor sammen.

Der er kendskab til i alt 280 anmeldelser indenfor idræt, spejder og øvrige områder som vedrører perioden fra 1980 til august 2003. Anmeldelserne fordeler sig med 189 inden for idræe, 64 inden for spejderbevægelsen og 27 inden for øvrige sammenhænge. Der findes i alt 219 domsafgjorte anmeldelser, hvor der er foretaget idømmelse af straf. 6 anmeldelser er endt med frifindelse. Desuden var der 16 anmeldelser, hvor gerningsmanden begik selvmord efter at have aflagt fuld tilståelse. Beregningsgrundlaget for undersøgelsen fordeler sig derfor med 160 inden for idræt, 52 inden for spejdere og 23 inden for øvrige områder. De resterende 39 sager er enten under nuværende politimæssig efterforskning, juridisk forberedelse, forældet eller henlagt pga. manglende beviser.

Krænkelserne spænder fra besiddelse af børneporno og blufærdighedskrænkelse til voldtægt. Det skal tilføjes, at antallet af mildere krænkelser som for eksempel blufærdighedskrænkelse ved berøring er væsentlig lavere for de udvalgte krænkelsessfærer, end hvad der er tilfældet for samfundet som helhed.

$90 \%$ af de idrætsrelaterede sager vedrører et rekreativt eller idrætsligt begynderniveau, hvoraf kampsport og ridning alene tegner sig for 59 afgjorte sager. $13 \%$ af sagerne har haft en varighed på 5 år eller derover, og den gennemsnitlige krænkelsesperiode er 7-12 måneder. I alt 71 krænkere i alderen 17-67 år, med en gennemsnitsalder på 35 år, har begået krænkelser mod minimum 221 børn og unge i alderen 6-17 år. I 65 \% af sagerne har der været tale om krænkelser af drenge mod $34 \%$ mod piger. Krænkelserne er primært foregået i krænkerens hjem eller i forbindelse med idrætslige faciliteter, stævner hytteture mm. Krænkerne inden for idræt har gennemsnitligt begået flere krænkelser pr. sag ligesom krænkelsesperioden generelt har varet længere tid, end det er tilfældet for spejderbevægelsen og øvrige felter. Undersøgelsen viser, at 9 ud af 10 børn/unge har været udsat for gentagne krænkelser, dvs. to eller flere krænkelser - enten inden for et døgn (der i definitionsmæssig forstand her er betragtet som engangstilfæelde) eller i forskellig tidsmæssig udstrækning indtil 6 år. Den mest udbredte belønning har været en kombination af flere privilegier ( $\mathrm{fx}$ at kunne komme og gå i trænerens hjem, ros og penge/gaver). Pressionsmidlerne har typisk været af mere indirekte og skjult karakter og appelleret til følelser af skyld og skam. I 9 ud af 10 tilfælde har den anvendte fremgangsmåde været knyttet an til en kombination af belønninger og en eller anden form for pression. Overtalelsen af udøveren er i ca. 4 ud af 10 tilfælde sket i forbindelse med indtagelse af alkohol - enten under private omstændigheder eller ved lejlighedsbestemte fester $\mathrm{i}$ idrætslig regi.

På baggrund af de præsenterede data kan det konkluderes, at idrætten er et særligt felt, hvor børn, unge og voksne - mænd og kvinder mødes omkring udprægede kropslige regimer. Man omgås hinanden på en særlig uformel måde i forbindelse med aktiviteterne, men i særdeleshed i det udvidede idrætslige rum som kan inkludere leg og kilderier, besøg i trænerens hjem og alkoholindtagelse til fester. Samtidig som disse omgangsformer giver mulighed for at ud- 
vikle noget godt og sundt, så giver disse adfærdskulturer også mulighed for misbrug. Resultaterne omkring brugen af belønning, pression og alkoholindtagelse understreger, at trænerens motivation/ tilbøjelighed er af central betydning for at udløse krænkelser. Det er primært sket gennem manipulation med udøverens sårbarhed og sekundært ved at udnytte de sociale praktikker og kulturelt betingede adfærdsformer, der ligger i idrætten. Krænkelsesperiodens varighed inden for idræt illustrerer netop betydningen af de tætte og intime relationer, og det er i denne optik, man bør forstå grænsenedbrydningsprocessen. En proces der sandsynligvis foregår i alle interpersonelle relationer, men pga. idrættens karakter og regimer relativ let kan forstærkes gennem berøringer og gradvis tilvænning. Idrættens relationer kan derfor karakteriseres som ansvarsrelationer med stærke komponenter af magt- og tillidsforhold.

Med afsæt i de ovenstående resultater kan man med rimelighed spørge, om det blot er en tilfældighed, at krænkerne i 100 $\%$ af tilfældene er mænd? Er det fordi mænd i højere grad mangler viden om, at det er forkert at indgå $\mathrm{i}$ intime relationer med udøvere under 18 år, eller skyldes det at mænds seksualitet generelt er mere aggressiv og udadvendt og i den anledning bedre er i stand til at tilsidesætte deres indre modstand mod at gøre det?

I forståelsen af, hvorfor seksuelle krænkelser forekommer, og hvorfor det er mænd, der udøver, er der i litteraturen bred enighed om, at der er tale om en problemstilling, som ikke blot skyldes drifter og seksuelle behov, men i højere grad skyldes ulige magtforhold og manglende ligestilling mellem mænd og kvinder. Den engelske sociolog Anthony Giddens hævder, bl.a. inspireret af den franske filosof Michel Foucaults teorier om magt og seksualitet, at mænds sociale, psykiske og fysiske krænkelser af kvinder skal ses som et udslag af mændenes manglende eller dalende kontrol. Men hvordan skal de omfattende krænkelser af drenge så forklares? Den psykologiske misbrugslitteratur er blandt andet parat med forklaringer om, at krænkerne selv har været udsat for krænkelser som børn og som følge heraf fortsætter med at krænke børn (drenge), når de selv bliver voksne. Når man ser på statistikkerne om intrafamiliære krænkelser, fremgår det, at det i højere grad er piger som udsættes for seksuelle krænkelser, og derfor synes det nærliggende at problematisere, hvorfor tidligere krænkede piger i modsætning til krænkede drenge ikke udvikler sig til voksne krænkere? Selvom $37 \%$ af ungdomstrænerne er kvinder, findes der ingen domsafgjorte sager, som omfatter kvindelige krænkere (Nielsen, 2004). Ud fra mit kendskab til problemstillingen er jeg kun bekendt med to konkret eksempler på kvindelige trænere, som har indgået i ulovlige seksuelle relationer, og problemet synes derfor relativeret $\mathrm{i}$ forhold til mandlige træneres krænkelser. I følge psykologen Libby Tata Arcel, som har beskæftiget sig med sexchikane på arbejdsmarkedet, udsætter mænd ikke alle kvinder, som de måtte være seksuel tiltrukket af, for seksuelle tilnærmelser, men først og fremmest, når de "kan komme af sted med det" uden konsekvenser for dem selv. For nylig trådte Bill Clinton frem i det amerikanske tv-program 60 minutes og forklarede, hvorfor han havde haft en affære med den kvindelige praktikant i det hvide hus, Monica Lewinsky: "I did it for the worst possible reason - I did it because I had the opportunity". I relation til seksuelle krænkelser i idræt er der også noget der tyder på, at specielt mandlige trænere falder for fristelsen og indleder seksuelle relationer med børn og unge, fordi de tror de kan slippe af sted med det uden konsekvenser for sig selv. Begrundelsen for krænkernes tilsyneladende tro på ikke at blive opdaget skal muligvis søges i idrættens uformelle omgangsformer, hvor grænserne for, hvad det er acceptabelt, langsomt forrykkes. I mange idrætslige kulturer findes der dybe traditioner for, at au- 
toritær ledelsesstil er legitimeret på lige fod med 3. halvlegs mandehørm i omklædningsrum, hvad enten der er tale om seksualiseret sprog, initieringsritualer eller alkoholindtagelse.

Spørgsmålet om, hvad man kan gøre for at forebygge krænkelsesforløb, rejser et mere principielt spørgsmål om det etiske grundlag for foreningsidrætten og navnlig hvilke regler, der skal gxlde for rekruttering og monitorering af foreningernes frivillige. Det synes klart, at idrætten tiltrækker folk, som er glade for børn og unge, herunder også voksne, der er lidt for glade for børn/unge. Her kan man så spørge, hvilke krav man med rimelighed kan og skal stille til de, der ønsker at gøre en frivillig og ulønnet indsats? Hvordan skal idrætten forholde sig til samfundets normer på den ene side og idrættens etikbegreber med sportsmanship og fairplay på den anden? Selvom idrætten har andre tolerancetærskler overfor kropslig og verbal intimitet, må også de kulturbestemte normer have en grænse. Skal grænsen eksempelvis sættes ved sejrsknus og trøstende kram, eller skal grænsen sættes ved mere markante fysiske eller seksuelle handlinger? Hvor grænsen skal gå i den enkelte situation, kan være svært at afgøre, men det synes uundgåeligt, at der et eller andet sted skal trækkes en streg i sandet - såvel juridisk som moralsk. Det forebyggelsesmæssige perspektiv handler således ikke om, hvad der er juridisk strafbart eller politisk korrekt, men snarere om en præcisering af, hvordan idrætten med dens særlige omgangsformer og tolerance i forhold til intimitet pålægger de ansvarlige trænere og ledere særlige forpligtelser.

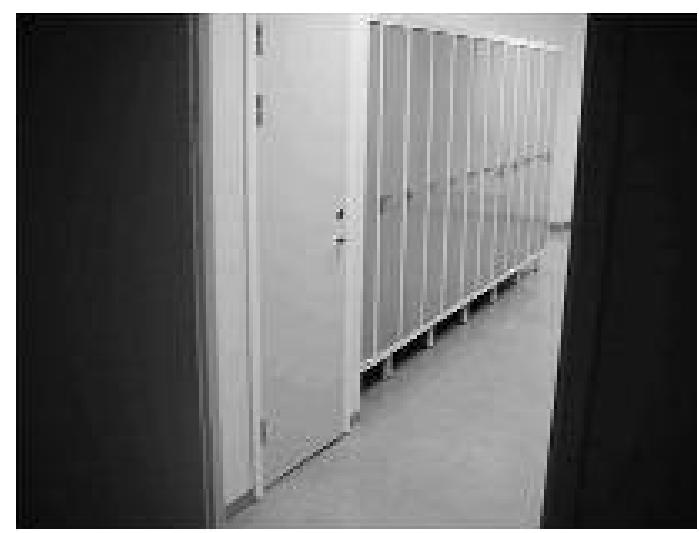




\section{NOTER}

1. Erfaringer fra krænkelsessager viser, at mange børn og unge stopper med at dyrke foreningsorganiseret idræt - enten på grund af krænkerens fortsatte færdsel i eller omkring idrætsmiljøet eller på grund af foreningens ofte mangelfulde håndtering af sagen. Det kan have konsekvenser for den krænkede udøver ikke at nå sine idrætslige mål og hvad vigtigere er - de sociale relationer til kammeraterne.

2. Helweg-Larsen gør ikke nærmere rede for, hvorfor det er sandsynligt, at differencen på $4 \%$ opstår, ligesom det såkaldte mørketal heller ikke problematiseres.

3. De gennemførte undersøgelser er ikke udtryk for en eksakt viden om omfang, men kan snarere betragtes som populationernes svarvillighed på det konkrete undersøgelsestidspunkt.

4. Omfangsundersøgelser fra Norge, Canada og Australien viser, at problemets størrelse varierer mellem $2 \%$ og $21 \%$ (Fasting m.fl. 2000, Kirby \& Greaves 1996, Leahy 2002).

5. Den procentmæssige uoverensstemmelse kan ikke umiddelbart forklares. Imidlertid kan man ikke forvente respondenter i skolealderen kan eller vil besvare spørgsmål om dette emne.

6. Contingency kan oversættes med eventualitet, mulighed og tilfælde.

Sagsakterne består typisk af domsudskrifter, kæreskrifter, fristforlængelsesrapporter, erstatningsanmodninger, begæringer om varetægtsfængsling, politirapporter med afhøringer af sigtede, anmelder, evt. vidner, mentalerklæringer samt videoafhøringer, bevismateriale (dagbøger, billeder, bånd $\mathrm{mm}$.).

7. Politiet i Grønland og Rønne har imidlertid fremsendt de relevante sager til gennemlæsning i København.

8. Fra anmeldelsen kommer politiet i hænde til der sker domsafsigelse, går der afhængig af sagens karakter og omfang mellem $\mathrm{l}$ og 12 måneder, inden sagen fremføres i retten. Sager, der herefter ankes for Landsretten, forlænges i reglen med yderligere 6-12 måneder. Den samlede periode kan derfor i visse tilfælde strække sig til over 2 år. For sager, der er anmeldt indenfor de seneste 12-24 måneder, kan disse således enten være blevet 1 . henlagt, 2 . befinde sig i en politimæssig efterforskningsfase, 3 . være under juridisk behandling eller 4. være under domstolenes behandling.

9. Grænsenedbrydningsteorien rummer en antagelse af, at idræts- og spejderaktive børn/unge udvikler en større tolerance i forhold til deres trænere og ledere, end der typisk vil være gældende for øvrige uformelle relationer.
10. De hyppigst nævnte krænkelser for drenge er 'homoseksualitet med barn u.12 år' henholdsvis 15 år, og for pigernes vedkommende er det primært 'samleje med barn u. 12 år' henholdsvis 15 år.

11. Trusler er herefter inddelt i verbale og fysiske handlinger, hvor den fysiske angrebshandling i forbindelse med et seksuelt overgreb ses som en skærpende omstændighed.

12. Ved at bestå smertemetoden kunne de opnå særlige udmærkelser i form af specielle sten; sten der ligeledes krævede, at man sværgede at hemmeligholde al viden om stenene. Overtrædelse af tabuet ville fă stenene til at miste kraft og udøveren til at miste retning. I andre tilfælde har krænkeren foretaget sædprøver eller kørt vatpinde rundt om penishovedet med det formål at undersøge drengenes potens og modenhed til indvielse i næste læringsniveau.

13. Tallet er et minimumstal, fordi der i 16 sagskomplekser er foretaget flere afhøringer og sigtelser, end der indgår i de endelige anklageskrifter. I 11 sagskomplekser er der modsat rejst flere anmeldelser vedrørende det samme barn. Hvis man skal dømme ud fra de tilgængelige sagskomplekser, vil det reelle antal af krænkede børn/unge sandsynligvis være betydeligt større, skønt et nærmere tal ikke kan angives. I en sag indrømmede krænkeren at have haft ca. 5.000 overnatninger med mere end hundrede børn/unge. En overnatning skal forstås som et barn en nat, hvor der foregik berøringer og onani. I den konkrete sag indstillede politiet afhøringerne efter at have registreret 16 krænkede. I en anden sag blev gerningsmanden dømt for krænkelser begået mod 11 forskellige drenge, hvor det imidlertid fremgår af sagsmaterialet, at der findes betydeligt flere krænkede børn/unge, som af forskellige grunde ikke ønskede at foretage anmeldelse.

\section{LITTERATUR}

- Brackenridge, C. (1990): “Cross Gender Relationships: Myth, Drama or Crisis", in Coaching Focus 1990/16, Leeds: National Coaching Foundation.

- Brackenridge, C. (1994): "Fair Play or Fair Game: Child Sexual Abuse in Sport Organisations", in International Review for the Sociology of Sport 1994/3.

- Brackenridge, C. (1996): Child Protection in Sport-Policies, Procedures and Systems. C\&GCHE - Cheltenham \& Gloucester College of Higher Education. 
- Brackenridge, C. (1997a): "Harassment and Sexual Abuse in Sport", in Gill Clarke \& Barbara Humberstone (eds.): Researching Women and Sport. Macmillan Press Ltd.

- Brackenridge, C. (1997b) "He owned me basically, Women's experience of sexual abuse in sport", in International

- Review for the Sociology of Sport 1997/32.

- Brackenridge, C. (2001): Spoilsports. Routledge, London and New York.

- Fasting, K., Brackenridge, C. \& Sundgot Borgen, J. (2000): Sexual Harassment In and Outside Sport. Oslo, Norwegian Olympic Committee. - Giddens, Anthony (1994): Intimitetens forandring. Hans Reitzels Forlag, København.

- Helweg-Larsen, K. (2000): Seksuelle overgreb mod born i Danmark. Statens Institut for Folkesundhed.

- Helweg-Larsen (2003): Seksuelle krenkelser inden for idret-Den aktuelle forekomst og forebyggelse. Kulturministeriet, København (rapporten tilgængelig på http://www.kum.dk/sw6579.asp) - Kirby, S. \& Greaves, L. (1996): "Foul play: sexual harassment in sport", artikel presenteret ved Pre-Olympic Scientific Congress, Dallas, Texas, USA, 11-14 juli.

- Leahy, T., Pretty, G. \& Tenenbaum, G. (2002):

"Prevalence of sexual abuse in organised competitive sport in Australia", in The Journal of Sexual Aggression, Volume Eight, Two.

- Leth, I., Stenvig, B. \& Pedersen, A. (1988):

"Seksuelle overgreb mod børn og unge - omfang og karakter", Nordisk Psykologi.

- Nielsen, J. (2004): Idrattens illusoriske Intimitet. Ph.d.afhandling, Institut for Idræt, København.

- Nielsen, J. (1998): Den forbudte Zone. Hovedfagsspeciale, Institut for Idræt, København.

\section{SUMMARY}

The article presents new data about prevalence and characteristics of sexual abuse in sport and discusses relevant gender perspectives. The results and discussion are based on a collection of 160 police files and court reports in which sport coaches have been convicted for perpetrating young athletes. According to 48 variables covering the perpetrator, the crime and the victim, all data have been placed in the KISS-database (Krenkelse I Sport Statistik). The most important findings show that the majority of victims are boys (63\%) opposed to girls (37\%). The average period of abuse is 7 to 12 months with $13 \%$ lasting 4-5 years or more. The empirical data validates the boundary erosion process theory, which points out that coaches through careful preparation, grooming and denial are able to abuse athletes without being exposed. The article draws attention to a gender perspective as it is documented that only men are found to exploit the exceptional opportunities that are granted by the extended tolerance of verbal and bodily intimacy in sport.

Jan Toftegaard Nielsen, cand.scient., ph.d. Institut for Idræt, Københavns Universitet. 